\title{
Effects of Various Processing Parameters on the Mechanical Properties of Sisal fiber/PES Composites Produced via Selective Laser Sintering
}

\begin{abstract}
Aboubaker I. B. Idriss, ${ }^{\text {a, b }}$ Jian Li, ${ }^{\text {a,* }}$ Yangwei Wang, ${ }^{\text {a }}$ Yanling Guo, ${ }^{\text {a }}$ and Elkhawad A. Elfaki ${ }^{\mathrm{c}}$

A new type of sustainable material, i.e., a sisal fiber/poly-ether sulfone composite (SFPC), which is energy-efficient, environmentally friendly, and has a low cost, was developed for laser sintering additive manufacturing. This study was performed to explore the effects of the processing parameters on the SFPC composite parts produced via selective laser sintering (SLS). The effects of the laser sintering processing parameters, i.e., the preheating temperature, laser power, and scan speed, were studied. Bending and tensile testing of the SFPC specimens was successfully performed via SLS. The effect of the processing parameters on the SLS in terms of the mechanical strength of the laser-sintered parts was investigated. The results determined that the processing parameters had a significant effect on the mechanical strength of the sintered SFPC parts. When the preheating temperature and laser power were increased in the processing SLS system, the mechanical strength of the sintered SFPC parts was significantly increased. However, the scanning speed had an inverse proportional relationship to the mechanical strength of the SFPC SLS parts.
\end{abstract}

Keywords: Selective laser sintering (SLS); Sisal fiber powder (SFP); Poly ether sulfone (PES) powder; Mechanical properties test

Contact information: a: College of Mechanical and Electrical Engineering, Northeast Forestry University, Harbin 150040 China; b: Department of Mechanical Engineering, Faculty of Engineering Science, University of Nyala, P.O. Box 155, Nyala Sudan; c: University of Bisha, College of Engineering, Mechanical Engineering Department, Bisha 61922 Saudi Arabia; Sudan University of Science and Technology, Department of Mechanical Engineering, College of Engineering, Khartoum 11113 Sudan;

Corresponding author: aboubakerbolad@yahoo.com

\section{INTRODUCTION}

Laser sintering or selective laser sintering (SLS) is one of the most established and widely used additive manufacturing (AM) techniques (Beaman et al. 1997; Guo et al. 2015; Yuan et al. 2016). In this process, an object is created layer-by-layer from a heat-fusible powdered material using the heat generated from a scanning laser beam (Guo et al. 2015; Bai et al. 2016). In general, all materials that can be either fused or melted can be used for the SLS process (Kim and Creasy 2004; Wohlers 2005; Yuan et al. 2016). The term 'laser sintering or SLS' is primarily applied to the processing of polymers, metals, ceramics, and composite materials (Leach et al. 2019; Tiwari et al. 2019). The principal advantage of SLS, when compared with other 3-D printing technologies, is the ability to create parts with enhanced geometric complexity and design flexibility, without needing additional expensive and specific tooling. Besides, the unsintered material can be recycled (Li et al. 2020b). 
SFPC is a biomass composite material ( $\mathrm{Li}$ et al. 2020a). The usage of a biomass composite material is well-suited for SLS because of the relatively low melting temperatures of such materials. Theoretically, all biomass materials, composites, polymers, metals, and ceramics available in powder form can be laser sintered by employing enhanced processing parameters (Bai et al. 2016; Yuan et al. 2016; Yu et al. 2018). However, these materials lack structural diversity and cannot completely meet the demand of the market; these issues have tended to inhibit the development of SLS applications.

To further improve the laser sintering process, there is a growing need to research and develop additional materials which can meet the various requirements for different industrial applications (Guo et al. 2014).

SFP is considered the most common and largest substantial waste source and recyclable material, with a short growth cycle. In addition, when compared to wood powder biomass materials, SPF has better mechanical properties, lower carbon emissions, and lower total energy consumption when used for SLS processing (Li et al. 2020a). SFPC powder has a wide range of AM applications, e.g., the furniture industry, wood composite purposes, construction purposes, and the manufacture of carpets, rugs, ropes, etc. (Li et al. 2020b). However, SFPC powder has not yet been commercially used as an SLS material. Many studies have reported success in processing biomass composite via SLS. Guo et al. (2014) proposed a novel approach for the use of natural and cheap forestry waste as the feedstock of SLS to reduce the price of a high-cost material. Besides, the use of forestry waste would reduce the environmental impact and increase the scope of material available for SLS. Several previous studies focused on various materials: sintered wood-plastic composites (WPC) (Zeng et al. 2013); rice husk powder/Co-polyether sulfone (PES) (RHPC) (Weiliang et al. 2012); walnut shell/Co-PES composites (Yu et al. 2017); and bamboo plastic composites (Yu et al. 2018). These studies focused on the mechanical properties of the laser-sintered biomass composite part. Based on the results of the previous studies, there is still a defect and lack in term of investigation of the effects of processing parameters on the biomass composite materials during the SLS process, as well as how it affects the mechanical strength of the SLS parts. Therefore, the quality of the sintered parts not only depends on the interaction mechanism of the laser beam and biomass composite powder but also depends on the SLS processing parameters. The SFPC is sintered via an AFS-360 SLS.

This study aims to explore the processing parameters influence on the mechanical properties of the SFPC SLS parts. In this paper, the effects of these parameters on the bending and tensile strength of the SFPC were investigated. The different processing parameters considered in this experiment are presented in Table 1. The SFPC used in this study was carefully prepared using a mixture ratio of (20/80 wt/wt) and an SFP particle size range of less than $0.105 \mathrm{~mm}$.

\section{EXPERIMENTAL}

\section{Materials}

The primary materials utilized in this experiment were SFP powder and polyethersulfone (PES) powder. The SFP powder was used as one of the materials for SFPC synthesis. This powder was selected due to its excellent properties, e.g., its highdensity $\left(1290 \mathrm{~kg} / \mathrm{m}^{3}\right)$ and high tensile breaking force $\left(2.55 \times 10^{-4} \mathrm{~N}\right)$, in addition to its low water content when compared to other fibers ( $\mathrm{Li}$ et al. 2020b). PES is a type of 
thermoplastic polymer with excellent comprehensive properties and a stable performance temperature range $\left(-100{ }^{\circ} \mathrm{C}\right.$ to $\left.200{ }^{\circ} \mathrm{C}\right)$, which was developed by the British Imperial Chemical Industry Group in the 1970s (Knoell et al. 1999). PES is one of the most widely used materials for special engineering plastics. The molecular structure of PES is primarily composed of three groups, the ether groups, sulfone groups, and a phenylene group (Knoell et al. 1999). Therefore, SFP and PES polymer powder were selected as the main ingredients for the synthesis of the SFPC. The SFP tended to make the SFPC piece more flexible and smoother; besides, it would increase in the accuracy of the dimensions of the SFPC SLS parts. (Li et al. 2020a). The SFP was supplied by Hangzhou Gaoke Industry and Trade Co., Ltd. (Zhejiang, China), while the PES powder was supplied by Shanghai TianNian Material Technology Co., Ltd. (Shanghai, China). Before mixing, the SFP was prepared alone; first, the SFP was screened via vibrating sieves to obtain a powder with a particle size of less than $0.105 \mathrm{~mm}$. Then, the sieved powder was placed into a DHG-9140 electric heating thermostat at a temperature of $100{ }^{\circ} \mathrm{C}$ for $5 \mathrm{~h}$ to $6 \mathrm{~h}$ to reduce water content. Finally, the SFP was cooled to room temperature in order to be used for SFPC material synthesis.

\section{Material Preparations}

The preparation process of the SFPC

First, the dried SFP was manually mixed with the PES powder. Then, the SFP and PES powders were mechanically mixed using an SHR-10A high-speed mixer (Hongji Machinery Ltd., Zhangjiagang, China) to obtain a proper uniformity. The mixture ratio for this experiment was 20/80 wt/wt. Figure 1 and Fig. 2 showed the composite preparation processes of the SFPC.
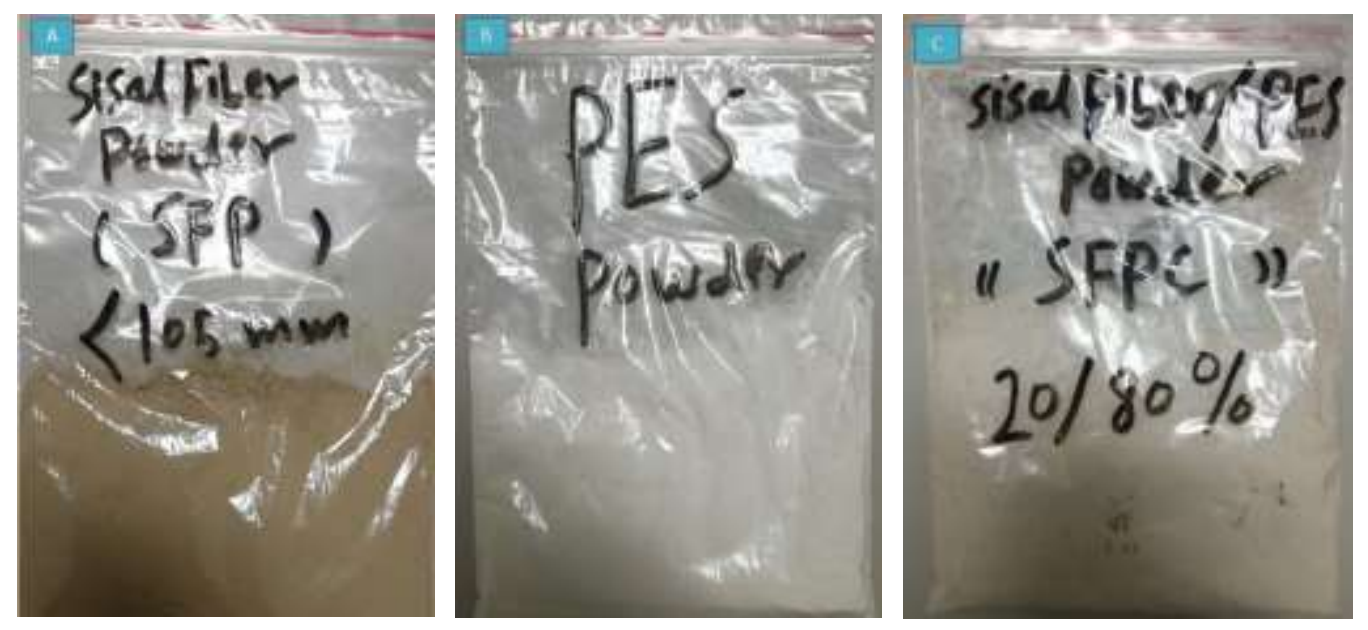

Fig. 1. The primary materials of the composite: (a) the sisal fiber powder (SFP); (b) the PES powder; and (c) the sisal fiber/PES composite (SFPC) powder

\section{Selective laser sintering processing of the SFPC}

SLS is an intelligent machine, provided with computer control to print and produce parts. To control the SLS machine, the AFS Win automatic moulding system could be used. Firstly, the moulding and powder supply cylinder of SLS were adjusted in the upper limit to adjust the SFPC in a cylinder of SLS. 


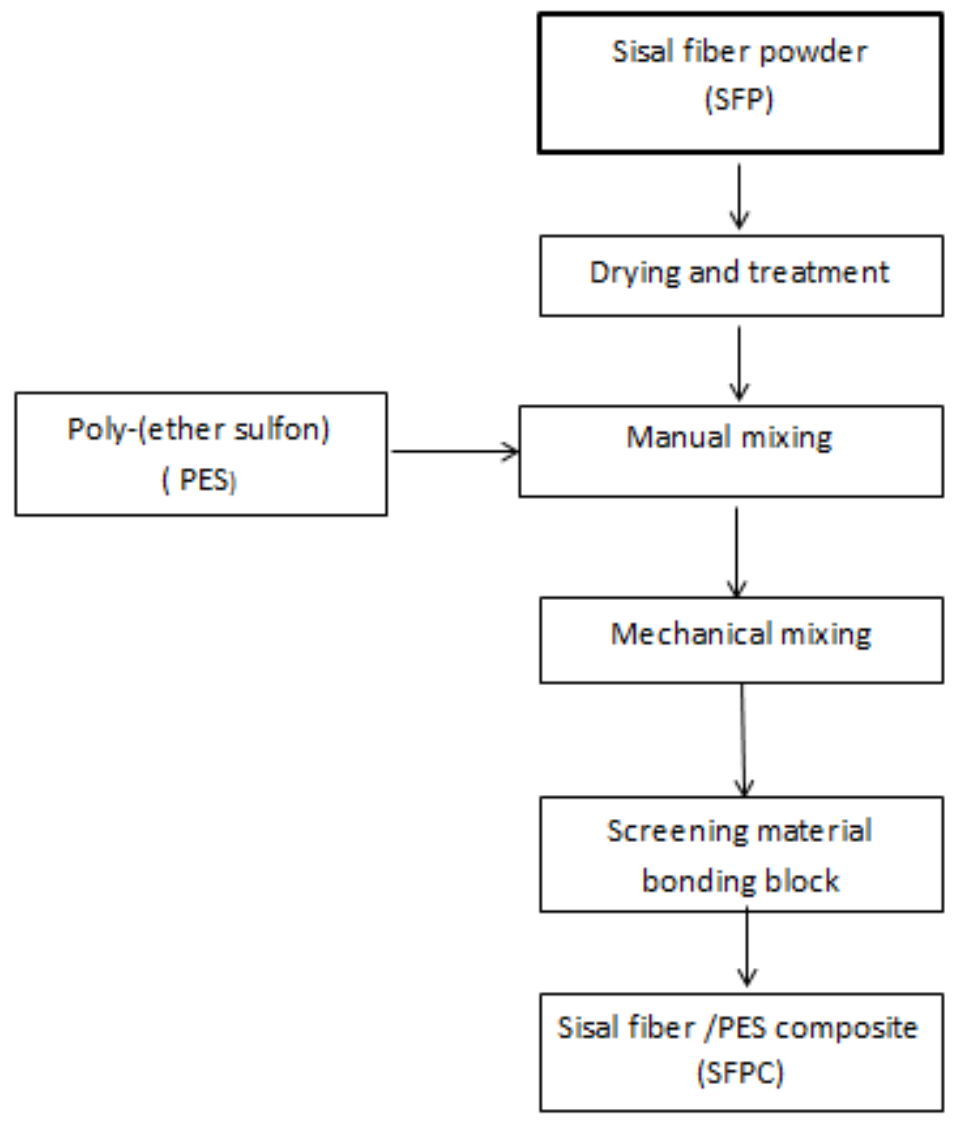

Fig. 2. A flow chart of the preparation process of the sisal fiber/PES composite powder

Table 1. The Proposed Processing Parameters Design for the Sisal Fiber/PES Composite (SFPC) Parts

\begin{tabular}{|c|c|c|c|c|c|}
\hline Parameters & $\begin{array}{c}\text { Preheating } \\
\text { Temperature }\end{array}$ & $\begin{array}{c}\text { Laser Power } \\
(\mathrm{w})\end{array}$ & $\begin{array}{c}\text { Scan Speed } \\
(\mathrm{m} / \mathrm{s})\end{array}$ & $\begin{array}{c}\text { Scan } \\
\text { Spacing } \\
(\mathrm{mm})\end{array}$ & $\begin{array}{c}\text { Layer } \\
\text { Thickness } \\
(\mathrm{mm})\end{array}$ \\
\hline $\begin{array}{c}\text { Sisal fiber/PES } \\
(1: 4) \mathrm{wt} / \mathrm{wt}\end{array}$ & $74^{\circ} \mathrm{C}$ & 10 & 1 & 0.2 & 0.1 \\
\hline $\begin{array}{c}\text { Sisal fiber/PES } \\
(20 / 80) \mathrm{wt} / \mathrm{wt}\end{array}$ & $78{ }^{\circ} \mathrm{C}$ & 12 & 1.5 & 0.2 & 0.1 \\
\hline $\begin{array}{c}\text { Sisal fiber/PES } \\
(20 / 80) \mathrm{wt} / \mathrm{wt}\end{array}$ & $82^{\circ} \mathrm{C}$ & 14 & 2 & 0.2 & 0.1 \\
\hline $\begin{array}{c}\text { Sisal fiber/PES } \\
(20 / 80) \mathrm{wt} / \mathrm{wt}\end{array}$ & $86^{\circ} \mathrm{C}$ & 16 & 2.5 & 0.2 & 0.1 \\
\hline $\begin{array}{c}\text { The Optimum } \\
\text { Parameters }\end{array}$ & $82^{\circ} \mathrm{C}$ & 14 & 2 & 0.2 & 0.1 \\
\hline
\end{tabular}

In this experiment, the SFPC test specimens that had a mixing ratio of $20 / 80 \mathrm{wt} / \mathrm{wt}$ were produced using an AFS-360 SLS machine. The varied processing parameters tested were as follows: laser power $(10 \mathrm{~W}, 12 \mathrm{~W}, 14 \mathrm{~W}$, and $16 \mathrm{~W})$, preheating temperature (74 ${ }^{\circ} \mathrm{C}, 78{ }^{\circ} \mathrm{C}, 82{ }^{\circ} \mathrm{C}$, and $\left.86{ }^{\circ} \mathrm{C}\right)$, and scanning speed $(1 \mathrm{~m} / \mathrm{s}, 1.5 \mathrm{~m} / \mathrm{s}, 2 \mathrm{~m} / \mathrm{s}$, and $2.5 \mathrm{~m} / \mathrm{s})$, with a constant scan spacing and layer thickness of $0.2 \mathrm{~mm}$ and $0.1 \mathrm{~mm}$, respectively. These parameters affected the forming quality and mechanical properties of the SFPC SLS parts. 
The specific influence of each processing parameter on the mechanical properties of SLS parts with the same mixing ratio was studied. Besides, a theoretical analysis of the experimental results also carried out. Figure 3 shows a flow chart that described the SFPC SLS processing.

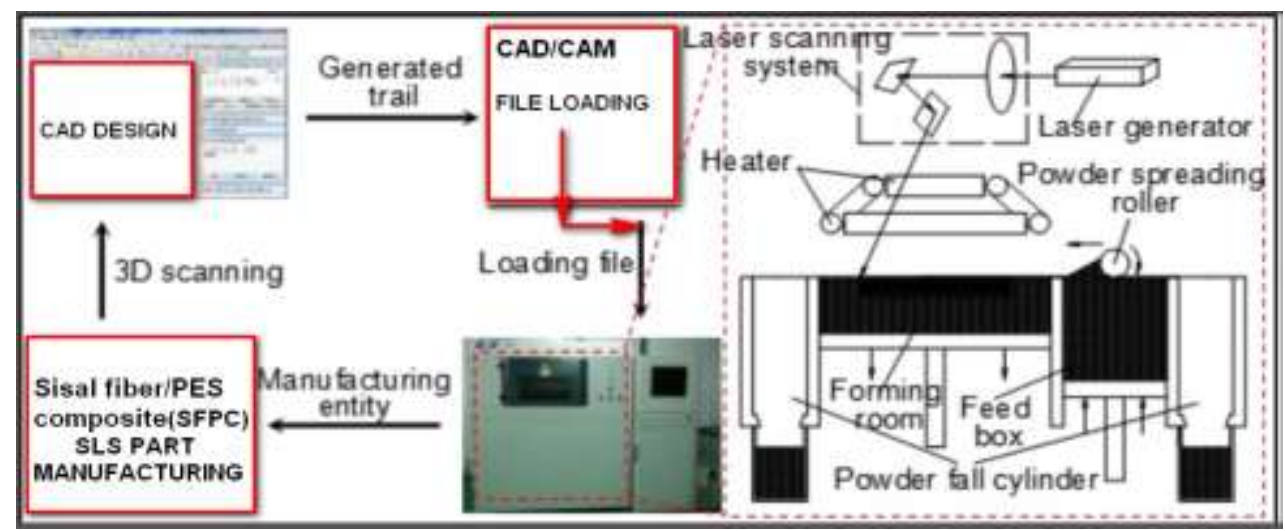

Fig. 3. A flow chart of the selective laser sintering processing

Scanning electron microscopy (SEM)

The SFP and the PES powder were scanned using a FEI Quanta 200 SEM scanning electron (Amsterdam, Netherlands). The SEM morphology of the SFP, the PES powder, and the composite powder (SFPC at a 20/80 wt/wt) were shown in Fig. 4.

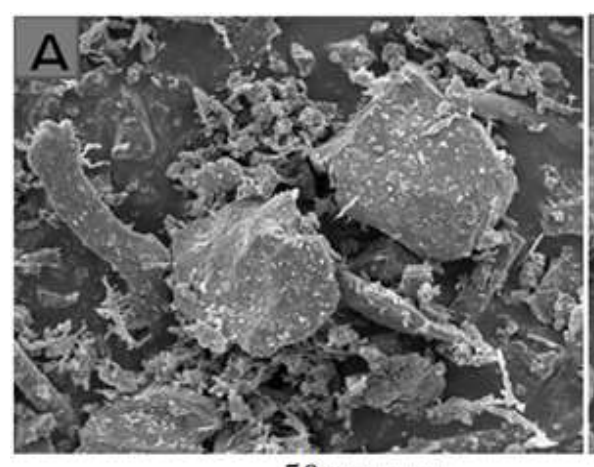

$50 \mu \mathrm{m}-\cdots---$

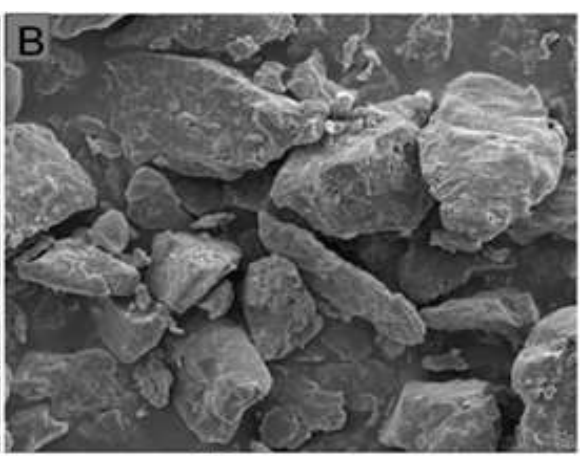

$50 \mu m--\cdot---$

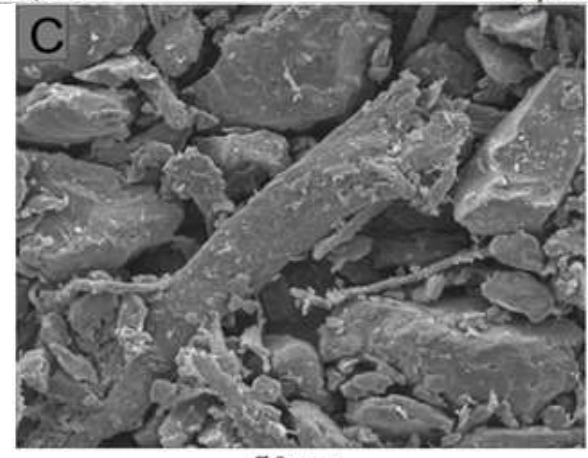

$50 \mu \mathrm{m}-$

Fig. 4. The SEM morphology of (a) the SFP with a particle size less than $0.105 \mathrm{~mm}$, (b) the PES powder, and (c) the SFPC with a mixture ratio of 20/80 wt/wt 


\section{Differential scanning calorimetry (DSC)}

The glass-transition temperature of the PES and SFP powder was analyzed via an American Pyris Diamond differential scanning calorimeter (Perkin Elmer, Waltham, MA). The testing parameters were as follows: the sample size used for the SFP, PES, and SFPC was $5 \mathrm{mg}$, the heating rate was $10^{\circ} \mathrm{C} / \mathrm{min}$, and the range of the testing temperatures was $20{ }^{\circ} \mathrm{C}$ to $240{ }^{\circ} \mathrm{C}$.The DSC curves of the PES powder and the SFP are presented in Fig. 5.

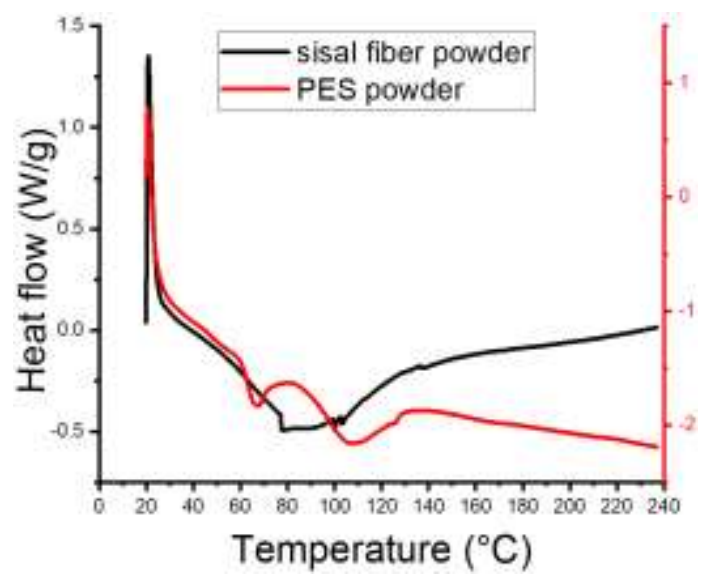

Fig. 5. The differential scanning calorimetry (DSC) curve of the PES and sisal fiber powders

\section{Mechanical tests}

The mechanical tests considered in this experiment were the bending and tensile specimens tests. The bending and tensile strength tests were designed according to the standard specifications given by a Byes-3003 universal testing machine. The bending specimen test was performed with a three-point loading test, and the STL format of the bending and tensile strength had dimensions of $80 \mathrm{~mm} \times 13 \mathrm{~mm} \times 4 \mathrm{~mm}$ and $150 \mathrm{~mm} \times$ $20 \mathrm{~mm} \times 10 \mathrm{~mm}$, respectively. The bending strength was determined using Eq. 1,

$$
\delta_{f}=\frac{3 F L}{2 b h^{2}}
$$

where $\delta_{F}$ is the bending strength (MPa), $F$ is the force applied $(\mathrm{N}), L$ is the length $(\mathrm{mm})$, $b$ is the sample width $(\mathrm{mm})$, and $h$ is the sample thickness $(\mathrm{mm})$. The specific dimensions of the tensile specimen test were as follows: a total length of $150 \mathrm{~mm} \pm 0.5 \mathrm{~mm}$, the length of the middle parallel part was $60 \mathrm{~mm} \pm 0.5 \mathrm{~mm}$, the width of the central parallel part was $10 \mathrm{~mm} \pm 0.2 \mathrm{~mm}$, the end width was $20 \mathrm{~mm} \pm 0.2 \mathrm{~mm}$, and the gauge length was $50 \mathrm{~mm}$ $\pm 0.5 \mathrm{~mm}$. In addition, the distance between the clamps was $115 \mathrm{~mm} \pm 5 \mathrm{~mm}$, the radius was $60 \mathrm{~mm} \pm 0.5 \mathrm{~mm}$, and the thickness was $4 \mathrm{~mm} \pm 0.2 \mathrm{~mm}$. The tensile strength was determined by Eq. 2,

$$
\delta_{t}=\frac{p}{b d}
$$

where $\delta_{T}$ is the tensile strength (MPa), $p$ is the maximum load (N), $b$ is the sample width $(\mathrm{mm})$, and $d$ is the sample thickness $(\mathrm{mm})$. In this experiment, testing the mechanical properties, i.e., the bending strength and tensile strength, were conducted using a Byes3003 universal testing machine (Jilin Province Taihe Ltd. Changchun, China). The results obtained from the bending strength and tensile strength tests were presented in Tables 2, 3, and 4 , and the results of an analysis of the mean at a 95\% confidence interval are presented in the same tables. 


\section{RESULTS AND DISCUSSION}

\section{Single Layer Sintering Experiment}

This study aimed to find the optimum processing parameters of the SFPC composite. Through several experiments determined the best SLS parameters for SFPC and PES parts, and was previously explained in Table 1 (Li et al. 2020a). The experimental test results in term of bending and tensile strength showed the effect of different processing parameters, i.e., the preheating temperature, the laser power, and the scan speed on the mechanical properties of SLS parts.

\section{Mechanical Test Analyses}

The purpose of this section is to explore the effects of the processing parameters on the bending and tensile strength of the SFPC parts produced via SLS. The test methods used to determine the mechanical properties parts were previously explained in the materials section.

The effect of the preheating temperature on the mechanical properties of the SFPC produced via $S L S$

A laser beam was used for SLS processing to transfer heat energy to the powder materials. However, a change in the absorption efficiency of the laser energy affected the heat energy transfer. As a result, the mechanical properties of the SLS parts were decreased. In order to improve the mechanical properties of the SLS parts, the SLS heating device should be used to preheat the whole processing system of the SLS machine. To print the four experimental bending and tensile test pieces, the scanning speed was set to $2 \mathrm{~m} / \mathrm{s}$, the laser power was set to $14 \mathrm{~W}$, and the preheating temperature was set to $74{ }^{\circ} \mathrm{C}, 78{ }^{\circ} \mathrm{C}, 82$ ${ }^{\circ} \mathrm{C}$, or $86{ }^{\circ} \mathrm{C}$. The mechanical test results of these pieces are shown in Fig. 6a, and Fig. 6 b. As shown in Fig. 6, a preheating temperature of $86{ }^{\circ} \mathrm{C}$ resulted in the SLS part with the highest mechanical strength, which amounted to a bending strength of $7.53 \mathrm{MPa}$ and tensile strength of $3.54 \mathrm{MPa}$. By comparing the mechanical strengths of the SLS parts produced under different preheating temperatures, the authors were able to identify a useful, i.e., positive, relationship between the preheating temperature and the mechanical strength of the SLS parts. The mechanical strength of the SFPC SLS part increased when the preheating temperature for the powder bed temperature was increased. When the preheating temperature of the whole processing system (powder bed temperature) rose from $74{ }^{\circ} \mathrm{C}$ to $78{ }^{\circ} \mathrm{C}$, the bending strength of the SLS parts was significantly increased, from 5.81 $\mathrm{MPa}$ to $6.72 \mathrm{MPa}$. When the preheating temperature of the powder bed temperature was increased from $82{ }^{\circ} \mathrm{C}$ to $86{ }^{\circ} \mathrm{C}$, the tensile strength of the SLS parts was marginally increased, from $3.24 \mathrm{MPa}$ to $3.54 \mathrm{MPa}$. Thus, a gradual increase in the preheating temperature of the powder bed temperature improved the mechanical properties of the SLS parts; this was due to an increase in the energy absorbed, and consequently, this improved the heat transfer efficiency of powder bed during the preheating stage. At a low preheating temperature, the energy absorbed by the powder material during the preheating stage was not sufficient; this led to a reduction in the heat transfer efficiency of powder material, and as a result, the mechanical strength of the sintered part was decreased. Thus, a proper preheating temperature for the SLS workpiece is necessary to achieve a highquality SLS part. 


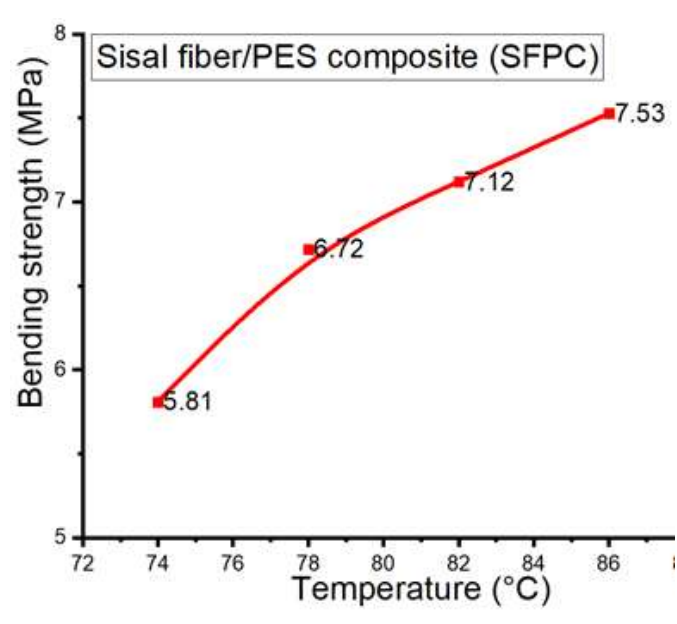

(a)

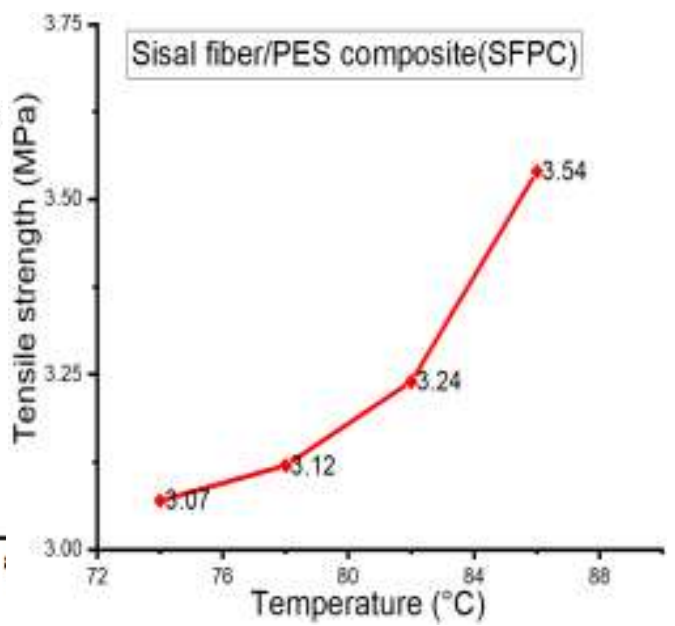

(b)

Fig. 6 The effect of the preheating temperature on the mechanical properties of the SFPC parts: (a) the bending strength curve of the preheating temperature; and (b) the tensile strength curve of the preheating temperature

The effect of the laser power on the mechanical properties of the SFPC produced via SLS

The principle behind the SLS process involves a laser beam that is emitted and focused into a high-energy spot. Then the powder material is sintered by moving this spot on the forming face of the SLS machine. The laser power is affected by the light intensity distribution of the laser beam, and the light intensity distribution of the laser beam is calculated by using Eq. 3,

$$
I(r)=\frac{2 P}{\pi \omega^{2}} \exp \left(-\frac{2 r^{2}}{\omega^{2}}\right)
$$

where $I$ is the light intensity of the laser beam (cd), $r$ is the distance between the inspection point and the spot center $(\mathrm{mm}), P$ is the laser power $(\mathrm{w})$, and $\omega$ is the characteristic radius $(\mathrm{mm})$.

To print the four experimental bending and tensile test pieces, the scanning speed was set to $2 \mathrm{~m} / \mathrm{s}$, the preheating temperature was set to $82{ }^{\circ} \mathrm{C}$, and the laser power was set to $10 \mathrm{~W}, 12 \mathrm{~W}, 14 \mathrm{~W}$, and $16 \mathrm{~W}$. The mechanical test results of these specimens are shown in Fig. 7a and Fig. 7b. As shown in Fig. 7, the SLS part with the highest mechanical strength was obtained when the laser power was $16 \mathrm{~W}$, which resulted in a bending strength of 9.47 $\mathrm{MPa}$ and a tensile strength of $4.93 \mathrm{MPa}$. Additionally, the mechanical properties of the SLS part increased as the laser power increased.

When the laser power raised from $12 \mathrm{~W}$ to $14 \mathrm{~W}$, the produced SLS part yielded the highest increase rate of bending and tensile strength value from $7.12 \mathrm{MPa}$ to $8.63 \mathrm{MPa}$ and 3.24 MPa to 4.93 MPa, respectively. Consequently, at a low laser power, low amounts of melting of the PES powder occurred during the sintering process, due to a reduction in the light intensity of the laser beam; this led to a failure between the sintering neck particles of the PES powder and the SFP.

When the laser power was too high, the mechanical properties of the SLS part were increased; however, the dimensional accuracy of the SLS part decreased, and the result is listed in the end of Table 6 . Therefore, the optimum laser power was necessary to confirm the quality of the SFPC SLS part. 


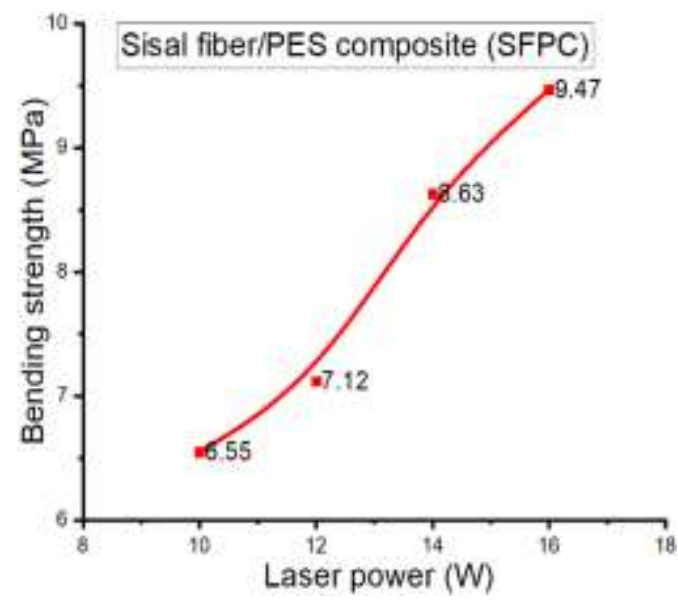

(a)

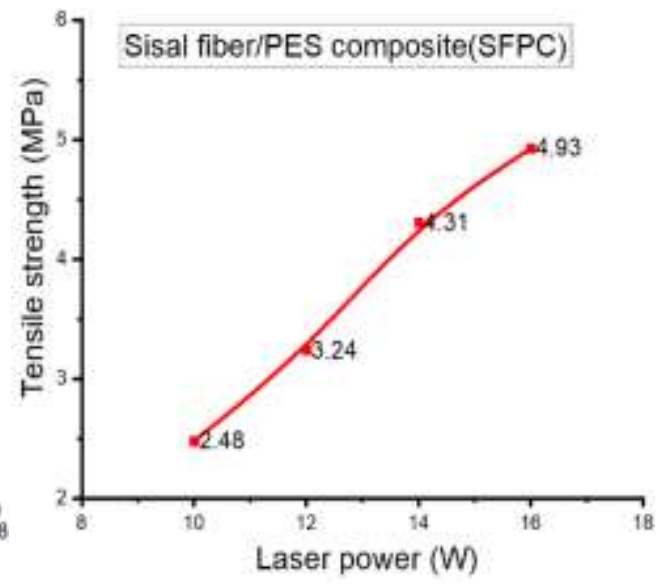

(b)

Fig. 7. The effect of the laser power on the mechanical properties of the SFPC parts: (a) the bending strength curve of the different laser powers; and (b) the tensile strength curve of the different laser powers

Effect of the scanning speed on the mechanical properties of the SFPC produced via SLS

For the SLS moulding process, the scanning speed defines the distance covered by the moving scanning laser beam. The influence of the scanning speed on the mechanical properties of the SLS parts was evaluated via the energy density of the cross-section laser scanning. The energy density distribution of the laser scanning line was calculated via Eq. 4 ,

$$
E(y)=\sqrt{\frac{2}{\pi}} \frac{P}{\omega v} \exp \left(-\frac{2 y^{2}}{\omega^{2}}\right)
$$

where $E$ is the section energy density, $\left(\mathrm{J} / \mathrm{mm}^{3}\right), y$ is the distance between the inspection point and the spot center $(\mathrm{mm}), P$ is the laser power $(\mathrm{w}), \omega$ is the characteristic radius, $(\mathrm{mm})$, and $v$ is the scanning speed $(\mathrm{mm} / \mathrm{s})$. To print the four experimental bending and tensile test pieces, the laser power was set to $14 \mathrm{~W}$, the preheating temperature was set to $82^{\circ} \mathrm{C}$, and the scanning speed was set to $1.0 \mathrm{~m} / \mathrm{s}, 1.5 \mathrm{~m} / \mathrm{s}, 2.0 \mathrm{~m} / \mathrm{s}$ or $2.5 \mathrm{~m} / \mathrm{s}$. The mechanical test results of the bending and tensile strength are shown in Fig. 8a and Fig. 8b. As shown in Fig. 8, when the scanning speed of the laser beam was $1.0 \mathrm{~m} / \mathrm{s}$, the mechanical strength of the SLS part was the highest value, which resulted in a bending strength of $11.08 \mathrm{MPa}$ and a tensile strength of $5.97 \mathrm{MPa}$. The scanning speed was inversely proportional to both the tensile and the bending strength of the SLS part. When the scanning speed was increased from $1.0 \mathrm{~m} / \mathrm{s}$ to $1.5 \mathrm{~m} / \mathrm{s}$, the sintered parts exhibited the largest decrease in the tensile strength (5.97 $\mathrm{MPa}$ to $4.53 \mathrm{MPa})$. Similarly, when the scanning speed was increased from $2.0 \mathrm{~m} / \mathrm{s}$ to $2.5 \mathrm{~m} / \mathrm{s}$, the bending strength of the sintered parts had the largest decline strength value (7.12 $\mathrm{MPa}$ to $4.41 \mathrm{MPa})$. When the scanning speed was gradually reduced, the mechanical strength of the sintered parts increased. From the analysis of the results, it found that a scanning speed of $0.5 \mathrm{~m} / \mathrm{s} \mathrm{had}$ a significant effect on the mechanical properties of the SLS part. However, a lower scanning speed of the laser beam required a longer time for the SLS process to complete. When the scanning speed was reduced, the laser beam sintering processing time and the energy density of the crosssection laser scanning were increased (Eq. 4). Therefore, the processing system exerted more heat on the powder material, leading to an increase in the mechanical properties of the sintered part. 


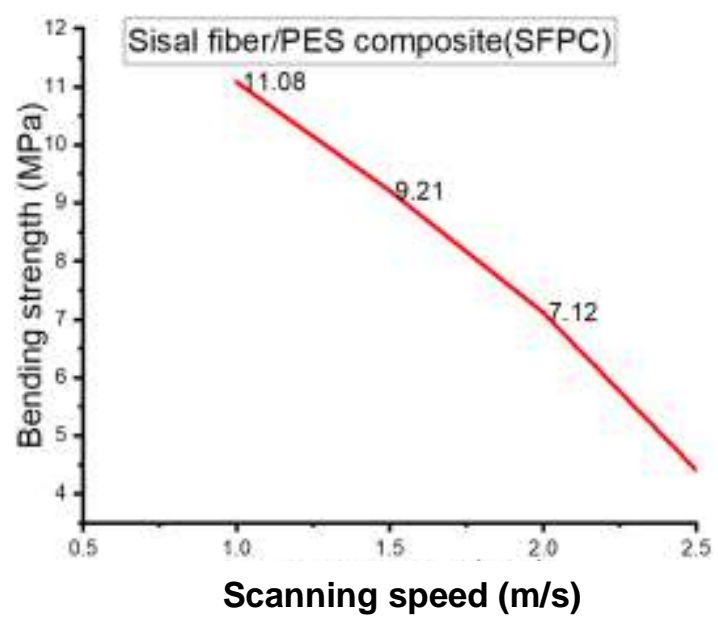

(a)

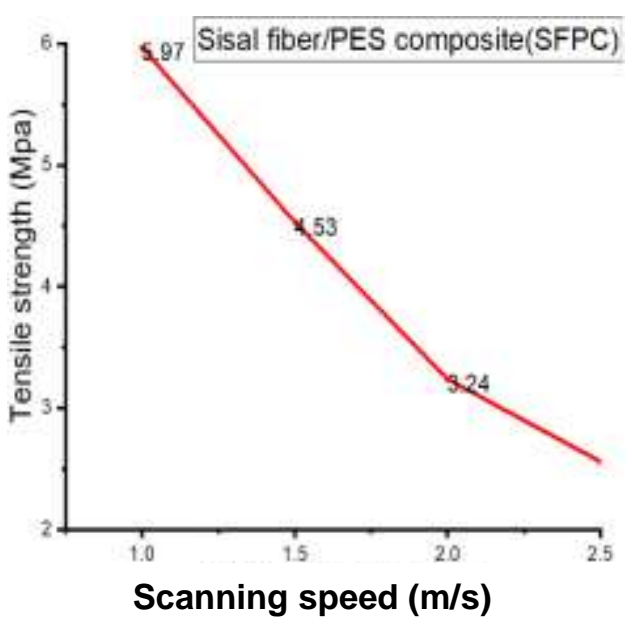

(b)

Fig. 8. The effect of the scanning speed on the mechanical properties of the SFPC parts: (a) the bending strength curve of the different scanning speed; and (b) the tensile strength curve of the different scanning speed.

Table 2. The Effect of Different Preheating Temperatures on the Mechanical Strength of SFPC SLS parts, including the $95 \%$ Confidence Interval for the Mean

\begin{tabular}{|c|c|c|c|c|c|c|c|c|c|c|c|c|}
\hline \multirow{2}{*}{$\begin{array}{l}\text { Preheating } \\
\text { Temp }\end{array}$} & \multicolumn{3}{|c|}{ Bending Strength } & \multirow{2}{*}{\multicolumn{2}{|c|}{ Mean }} & \multicolumn{3}{|c|}{ Tensile Strength } & \multirow{2}{*}{\multicolumn{2}{|c|}{ Mean }} & \multicolumn{2}{|c|}{$\begin{array}{l}\text { Standard Deviation } \\
\text { for the Test }\end{array}$} \\
\hline & $\begin{array}{l}\text { Test } \\
1\end{array}$ & $\begin{array}{c}\text { Test } \\
2\end{array}$ & $\begin{array}{c}\text { Test } \\
3\end{array}$ & & & $\begin{array}{l}\text { Test } \\
1 \\
\end{array}$ & $\begin{array}{c}\text { Test } \\
2 \\
\end{array}$ & \begin{tabular}{|c|} 
Test \\
3 \\
\end{tabular} & & & $\begin{array}{l}\text { Bending } \\
\text { Strength }\end{array}$ & $\begin{array}{l}\text { Tensile } \\
\text { Strength }\end{array}$ \\
\hline \multirow[b]{2}{*}{$74^{\circ} \mathrm{C}$} & \multirow{2}{*}{5.78} & \multirow[b]{2}{*}{5.82} & \multirow[b]{2}{*}{5.84} & \multirow[b]{2}{*}{5.81} & $\begin{array}{l}\text { Lowe } \\
r= \\
5.162\end{array}$ & \multirow[b]{2}{*}{3.1} & \multirow[b]{2}{*}{3.05} & \multirow[b]{2}{*}{3.06} & \multirow[b]{2}{*}{3.07} & $\begin{array}{l}\text { Lower } \\
= \\
2.422\end{array}$ & \multirow[b]{2}{*}{$\begin{array}{l}0.030550 \\
505\end{array}$} & \multirow[t]{2}{*}{\begin{tabular}{|l|}
0.02645 \\
7513
\end{tabular}} \\
\hline & & & & & $\begin{array}{l}\text { Uppe } \\
r= \\
6.458\end{array}$ & & & & & $\begin{array}{l}\text { Upper } \\
= \\
3.718\end{array}$ & & \\
\hline \multirow[b]{2}{*}{$78^{\circ} \mathrm{C}$} & \multirow[b]{2}{*}{6.76} & \multirow[b]{2}{*}{6.69} & \multirow[b]{2}{*}{6.71} & \multirow[b]{2}{*}{6.72} & $\begin{array}{l}\text { Lowe } \\
r= \\
6.072\end{array}$ & \multirow[b]{2}{*}{3.15} & \multirow[b]{2}{*}{3.09} & \multirow[b]{2}{*}{3.13} & \multirow[b]{2}{*}{3.12} & $\begin{array}{l}\text { Lower } \\
= \\
2.472\end{array}$ & \multirow[b]{2}{*}{$\begin{array}{l}0.036055 \\
513\end{array}$} & \multirow[t]{2}{*}{$\begin{array}{l}0.03055 \\
0505\end{array}$} \\
\hline & & & & & $\begin{array}{l}\text { Uppe } \\
r= \\
7.368\end{array}$ & & & & & $\begin{array}{l}\text { Upper } \\
= \\
3.678\end{array}$ & & \\
\hline \multirow{2}{*}{$82^{\circ} \mathrm{C}$} & \multirow[b]{2}{*}{7.06} & \multirow[b]{2}{*}{7.14} & \multirow[b]{2}{*}{7.17} & \multirow[b]{2}{*}{7.12} & $\begin{array}{l}\text { Lowe } \\
r= \\
6.472\end{array}$ & \multirow[b]{2}{*}{3.27} & \multirow[b]{2}{*}{3.25} & & & $\begin{array}{l}\text { Lower } \\
= \\
2.592\end{array}$ & & $\begin{array}{l}0.03605 \\
5513\end{array}$ \\
\hline & & & & & $\begin{array}{l}\text { Uppe } \\
r= \\
7.768\end{array}$ & & & 3.2 & 3.24 & $\begin{array}{l}\text { Upper } \\
= \\
3.887\end{array}$ & $\begin{array}{l}0.056862 \\
407\end{array}$ & \\
\hline & & & & & $\begin{array}{l}\text { Lowe } \\
r= \\
6.882\end{array}$ & & & & & $\begin{array}{l}\text { Lower } \\
= \\
2.892\end{array}$ & $\begin{array}{l}0.020816 \\
66\end{array}$ & $\begin{array}{l}0.02645 \\
7513\end{array}$ \\
\hline $86^{\circ} \mathrm{C}$ & 7.55 & 7.51 & 7.54 & 7.53 & $\begin{array}{l}\text { Uppe } \\
r= \\
8.178\end{array}$ & 3.57 & 3.52 & 3.53 & 3.54 & $\begin{array}{l}\text { Upper } \\
= \\
4.188\end{array}$ & & \\
\hline
\end{tabular}

Note: the upper and lower limits after the means are the $95 \%$ confidence intervals for the means 
A sintered part with a high moulding density had high mechanical properties. At a too fast scanning speed the sintering time of the powder material and the cross-sectional energy density of the laser scanning line are reduced; consequently, the powder material is melted and bonded because its unable to absorb sufficient heat, which caused to a reduction in the mechanical strength of SLS part. The potential applications of the developed SFPC composites could be used for AM process applications, such as the furniture industry, wood composite purposes, construction purposes, and the manufacturing of carpets and rugs.

Table 3. The Effect of Different Laser Powers on the Mechanical Strength of SFPC SLS parts, including the $95 \%$ Confidence Interval for the Mean

\begin{tabular}{|c|c|c|c|c|c|c|c|c|c|c|c|c|}
\hline \multirow{2}{*}{$\begin{array}{l}\text { Laser } \\
\text { Power } \\
\text { (W) }\end{array}$} & \multicolumn{3}{|c|}{$\begin{array}{c}\text { Bending Strength } \\
\text { Test }\end{array}$} & \multirow{2}{*}{\multicolumn{2}{|c|}{ Mean }} & \multicolumn{3}{|c|}{$\begin{array}{c}\text { Tensile Strength } \\
\text { Test }\end{array}$} & \multirow{2}{*}{\multicolumn{2}{|c|}{ Mean }} & \multicolumn{2}{|c|}{$\begin{array}{l}\text { Standard Deviation } \\
\text { for the Test }\end{array}$} \\
\hline & $\begin{array}{l}\text { Test } \\
1 \\
\end{array}$ & $\begin{array}{c}\text { Test } \\
2\end{array}$ & $\begin{array}{c}\text { Test } \\
3\end{array}$ & & & $\begin{array}{c}\text { Test } \\
1\end{array}$ & $\begin{array}{c}\text { Test } \\
2\end{array}$ & $\begin{array}{c}\text { Test } \\
3\end{array}$ & & & $\begin{array}{l}\text { Bending } \\
\text { Strength }\end{array}$ & $\begin{array}{l}\text { Tensile } \\
\text { Strength }\end{array}$ \\
\hline \multirow{2}{*}{10} & \multirow{2}{*}{6.51} & \multirow{2}{*}{6.62} & \multirow{2}{*}{6.53} & \multirow{2}{*}{6.55} & $\begin{array}{l}\text { Lower } \\
= \\
5.902\end{array}$ & \multirow{2}{*}{2.5} & \multirow{2}{*}{2.51} & \multirow{2}{*}{2.44} & \multirow{2}{*}{$\begin{array}{c}2.4 \\
8\end{array}$} & $\begin{array}{c}\text { Lower } \\
= \\
1.832\end{array}$ & $\begin{array}{c}0.058594 \\
653\end{array}$ & $\begin{array}{c}0.037859 \\
389\end{array}$ \\
\hline & & & & & $\begin{array}{l}\text { Upper } \\
= \\
7.198\end{array}$ & & & & & $\begin{array}{c}\text { Upper } \\
= \\
3.128\end{array}$ & & \\
\hline \multirow{2}{*}{12} & \multirow{2}{*}{6.95} & \multirow{2}{*}{7.19} & \multirow{2}{*}{7.22} & \multirow{2}{*}{7.12} & $\begin{array}{l}\text { Lower } \\
= \\
6.472\end{array}$ & \multirow{2}{*}{3.30} & \multirow{2}{*}{3.18} & \multirow{2}{*}{3.23} & \multirow{2}{*}{$\begin{array}{c}3.2 \\
4\end{array}$} & $\begin{array}{l}\text { Lower } \\
= \\
2.592\end{array}$ & \multirow[t]{2}{*}{$\begin{array}{c}0.147986 \\
486\end{array}$} & \multirow[t]{2}{*}{$\begin{array}{c}0.060277 \\
138\end{array}$} \\
\hline & & & & & $\begin{array}{l}\text { Upper } \\
= \\
7.768\end{array}$ & & & & & $\begin{array}{c}\text { Upper } \\
= \\
3.888\end{array}$ & & \\
\hline \multirow{2}{*}{14} & \multirow{2}{*}{8.68} & \multirow{2}{*}{8.62} & \multirow{2}{*}{8.59} & \multirow{2}{*}{8.63} & $\begin{array}{l}\text { Lower } \\
= \\
7.982\end{array}$ & \multirow{2}{*}{4.29} & \multirow{2}{*}{4.34} & \multirow{2}{*}{4.3} & \multirow{2}{*}{$\begin{array}{c}4.3 \\
1\end{array}$} & $\begin{array}{l}\text { Lower } \\
= \\
3.662\end{array}$ & \multirow[t]{2}{*}{$\begin{array}{c}0.045825 \\
757\end{array}$} & \multirow[t]{2}{*}{$\begin{array}{c}0.026457 \\
513\end{array}$} \\
\hline & & & & & $\begin{array}{l}\text { Upper } \\
= \\
9.278\end{array}$ & & & & & $\begin{array}{l}\text { Upper } \\
\quad= \\
4.958\end{array}$ & & \\
\hline \multirow{2}{*}{16} & & & & & $\begin{array}{l}\text { Lower } \\
= \\
8.822\end{array}$ & & & & 4.9 & $\begin{array}{l}\text { Lower } \\
= \\
4.282\end{array}$ & $\begin{array}{c}0.043588 \\
989\end{array}$ & 0.02 \\
\hline & $0.4<$ & $0.4 \mathrm{~J}$ & 5.5 & 5.41 & $\begin{array}{l}\text { Upper } \\
= \\
10.118\end{array}$ & 4.50 & 4.51 & 4.50 & 3 & $\begin{array}{l}\text { Upper } \\
= \\
5.578\end{array}$ & & \\
\hline
\end{tabular}


Table 4. The Effect of Different Scanning Speed on the Mechanical Strength of SFPC SLS Parts, Including the 95\% Confidence Interval for the Mean

\begin{tabular}{|c|c|c|c|c|c|c|c|c|c|c|c|c|}
\hline \multirow{2}{*}{$\begin{array}{l}\text { Scanning } \\
\text { Speed } \\
(\mathrm{m} / \mathrm{s})\end{array}$} & \multicolumn{3}{|c|}{ Bending Strength } & \multirow{2}{*}{\multicolumn{2}{|c|}{ Mean }} & \multicolumn{3}{|c|}{ Tensile Strength } & \multirow{2}{*}{\multicolumn{2}{|c|}{ Mean }} & \multicolumn{2}{|c|}{$\begin{array}{l}\text { Standard Deviation } \\
\text { for the Test }\end{array}$} \\
\hline & Test 1 & $\begin{array}{c}\text { Test } \\
2\end{array}$ & $\begin{array}{c}\text { Test } \\
3\end{array}$ & & & $\begin{array}{l}\text { Test } \\
1\end{array}$ & $\begin{array}{c}\text { Test } \\
2\end{array}$ & $\begin{array}{c}\text { Test } \\
3\end{array}$ & & & $\begin{array}{l}\text { Bending } \\
\text { Strength }\end{array}$ & $\begin{array}{l}\text { Tensile } \\
\text { Strength }\end{array}$ \\
\hline \multirow{2}{*}{1} & \multirow[t]{2}{*}{11.04} & \multirow[t]{2}{*}{11.07} & \multirow[t]{2}{*}{11.13} & \multirow[t]{2}{*}{11.08} & $\begin{array}{l}\text { Lower= } \\
11.015\end{array}$ & \multirow[t]{2}{*}{6.02} & \multirow[t]{2}{*}{5.94} & \multirow[t]{2}{*}{5.95} & \multirow[t]{2}{*}{5.97} & $\begin{array}{l}\text { Lower = } \\
5.322\end{array}$ & \multirow[t]{2}{*}{$\begin{array}{l}0.04582 \\
5757\end{array}$} & \multirow[t]{2}{*}{$\begin{array}{l}0.04358 \\
8989\end{array}$} \\
\hline & & & & & $\begin{array}{l}\text { Upper= } \\
12.448\end{array}$ & & & & & $\begin{array}{l}\text { Upper }= \\
6.618\end{array}$ & & \\
\hline \multirow{2}{*}{1.5} & \multirow[t]{2}{*}{9.23} & \multirow[t]{2}{*}{9.17} & \multirow[t]{2}{*}{9.24} & \multirow[t]{2}{*}{9.21} & $\begin{array}{l}\text { Lower } \\
=8.562\end{array}$ & \multirow[t]{2}{*}{4.58} & \multirow[t]{2}{*}{4.5} & \multirow[t]{2}{*}{4.51} & \multirow[t]{2}{*}{4.53} & $\begin{array}{l}\text { Lower }= \\
3.882\end{array}$ & \multirow[t]{2}{*}{$\begin{array}{l}0.03785 \\
9389\end{array}$} & \multirow[t]{2}{*}{$\begin{array}{l}0.04358 \\
8989\end{array}$} \\
\hline & & & & & $\begin{array}{l}\text { Upper } \\
=9.858 \\
\end{array}$ & & & & & $\begin{array}{l}\text { Upper }= \\
5.178\end{array}$ & & \\
\hline \multirow{2}{*}{2} & \multirow[t]{2}{*}{6.95} & \multirow[t]{2}{*}{7.19} & \multirow[t]{2}{*}{7.22} & \multirow[t]{2}{*}{7.12} & $\begin{array}{l}\text { Lower } \\
=6.472\end{array}$ & \multirow[t]{2}{*}{3.30} & \multirow[t]{2}{*}{3.18} & \multirow[t]{2}{*}{3.23} & \multirow[t]{2}{*}{3.24} & $\begin{array}{l}\text { Lower }= \\
2.592\end{array}$ & \multirow[t]{2}{*}{$\begin{array}{l}0.14798 \\
6486\end{array}$} & $\begin{array}{l}0.06027 \\
7138\end{array}$ \\
\hline & & & & & $\begin{array}{l}\text { Upper } \\
=7.768\end{array}$ & & & & & $\begin{array}{l}\text { Upper }= \\
3.888\end{array}$ & & \\
\hline & 4.39 & 4.47 & 4.38 & 4.41 & $\begin{array}{l}\text { Lower } \\
=3.762\end{array}$ & 2.53 & 2.54 & 2.61 & 2.56 & $\begin{array}{l}\text { Lower }= \\
1.912\end{array}$ & $\begin{array}{l}0.04932 \\
8829\end{array}$ & $\begin{array}{l}0.04358 \\
8989\end{array}$ \\
\hline 2.5 & & & & & $\begin{array}{l}\text { Upper } \\
=5.058\end{array}$ & & & & & $\begin{array}{l}\text { Upper }= \\
3.208\end{array}$ & & \\
\hline
\end{tabular}

Note: the upper and lower limits after the means are the $95 \%$ confidence intervals for the means

Table 5. Mechanical Properties Comparison between the Sisal fiber Composite (SFPC) and Wood-plastic Produced under the Same Mixture Ratio

\begin{tabular}{|c|c|c|}
\hline & Current Study & Guo et al. 2011 \\
\hline Parameter & $\begin{array}{c}\text { Sisal fiber composite SLS part } \\
\text { SFPC }(20 / 80 \mathrm{wt} / \mathrm{wt})\end{array}$ & Wood-plastic SLS part 20/80 wt/wt \\
\hline $\begin{array}{c}\text { Bending strength } \\
(\mathrm{MPa})\end{array}$ & 7.12 & 3.22 \\
\hline $\begin{array}{c}\text { Tensile strength } \\
(\mathrm{MPa})\end{array}$ & 3.24 & 2.17 \\
\hline
\end{tabular}

Table 6. Dimensions Accuracy Comparison between the SFPC SLS Parts Produced at Different Laser Power

\begin{tabular}{|c|c|c|c|}
\hline $\begin{array}{c}\text { SLS part at various } \\
\text { Laser power }\end{array}$ & $\begin{array}{c}\text { X Direction Accuracy } \\
(\%)\end{array}$ & $\begin{array}{c}\text { Y Direction Accuracy } \\
(\%)\end{array}$ & $\begin{array}{c}\text { Z Direction Accuracy } \\
(\%)\end{array}$ \\
\hline $10 \mathrm{~W}$ & 99.95 & 99.47 & 96.75 \\
\hline $12 \mathrm{~W}$ & 99.90 & 98.76 & 90.75 \\
\hline $14 \mathrm{~W}$ & 99.79 & 95.59 & 79.25 \\
\hline $16 \mathrm{~W}$ & 99.68 & 94.28 & 64.75 \\
\hline
\end{tabular}

Sintering temperature of the SFPC

SLS technology is a method that mainly depends on thermal influences. However, SFP has no melting point, and PES is an amorphous polymer; thus, the PES powder plays a significant role in the formation of SFPC composite. The glass transition temperature of PES and SFP were found through the DSC test, and then the SLS processing and preheating temperatures were determined accordingly to DSC result curve. To prevent the SFPC 
sintered parts from warping in the process of sintering, the powder material was preheated within a specific temperature range based on the DSC test. The temperature range represents the sintering window, which, as presented in $\left(T_{\mathrm{s}}\right.$ and $\left.T_{\mathrm{c}}\right) . T_{\mathrm{s}}$ is the softening point, while $T_{\mathrm{c}}$ is the caking temperature. PES is a non-crystallizable polymer; $T_{\mathrm{s}}$ is the glass transition temperature $\left(T_{\mathrm{g}}\right)$ of PES and SFP powders. However, $T_{\mathrm{c}}$ cannot found from the DSC curves, but it observed through the experiment. The DSC curves of the PES and SFP powders are shown in Fig. 5, where $T_{\mathrm{g}}$ equal $72{ }^{\circ} \mathrm{C}$ for PES powder and $70{ }^{\circ} \mathrm{C}$ for SFP powder. Through the experiments, it can be observed that the PES and SFP powders can be completely caking at $\left(97^{\circ} \mathrm{C}\right.$ and $\left.100{ }^{\circ} \mathrm{C}\right)$, respectively. Consequently, the sintering windows of the PES and SFP powders are between $\left(72{ }^{\circ} \mathrm{C}\right.$ to $\left.97{ }^{\circ} \mathrm{C}\right)$ and $\left(70{ }^{\circ} \mathrm{C}\right.$ to $\left.100{ }^{\circ} \mathrm{C}\right)$, respectively. To produce the SFPC parts the preheating temperatures was set within temperature ranges. Consequently, the preheating temperature of the SFPC composite was selected within a temperature range, which as $\left(74{ }^{\circ} \mathrm{C}, 78{ }^{\circ} \mathrm{C}, 82^{\circ} \mathrm{C}\right.$, and $\left.86{ }^{\circ} \mathrm{C}\right)$.

\section{CONCLUSIONS}

1. The test results of the experimental sintered parts determined that the processing parameters had a significant effect on the bending and tensile strengths of the sisal fiber/poly-ether sulfone composites with selective laser sintering (SFPC SLS) parts.

2. When the preheating temperature and laser power were increased in the SLS processing system, the mechanical strength of the SLS parts was proportionally increased. However, the scanning speed parameter was inversely related to the mechanical strength of the SFPC SLS part; a fast scanning speed resulted in low mechanical strength.

3. Finally, from the comprehensive experimental analysis, it was found that the quality of the SFPC SLS part was strongly dependent on the processing parameters of the whole processing system.

\section{ACKNOWLEDGEMENTS}

This work was supported in part by the Fundamental Research Funds for the Central Universities under Grant 2572018BF04 and in part by the National Natural Science Foundation of China (NO.51905084).

\section{REFERENCES CITED}

Bai, J., Zhang, B., Song, J., Bi, G., Wang, P., and Wei, J. (2016). "The effect of processing conditions on the mechanical properties of polyethylene produced by selective laser sintering," Polymer Testing 52, 89-93. DOI:

10.1016/j.polymertesting.2016.04.004

Beaman, J. J., Barlow, J. W., Bourell, D. L., Crawford, R. H., Marcus, H. L., and McAlea, K. P. (1997). "Process methods," in: Solid Freeform Fabrication: A New Direction in Manufacturing, Kluwer Academic Publishers, Norwell, MA, pp. 25-49. DOI: $10.1007 / 978-1-4615-6327-3$ 
Guo, Y., Jiang, K., and Bourell, D. L. (2014). "Preparation and laser sintering of limestone PA 12 composite," Polymer Testing 37, 210-215. DOI: 10.1016/j.polymertesting.2014.06.002

Guo, Y., Jiang, K., and Bourell, D. L. (2015). “Accuracy and mechanical property analysis of LPA12 parts fabricated by laser sintering," Polymer Testing 42, 175-180. DOI: 10.1016/j.polymertesting.2015.01.019

Kim, J., and Creasy, T. S. (2004). "Selective laser sintering characteristics of nylon 6/clay-reinforced nanocomposite," Polymer Testing 23(6), 629-636. DOI: 10.1016/j.polymertesting.2004.01.014

Knoell, T., Safarik, J., Cormack, T., Riley, R., Lin, S. W., and Ridgway, H. (1999). "Biofouling potentials of microporous polysulfone membranes containing a sulfonated polyether-ethersulfone/polyethersulfone block copolymer: Correlation of membrane surface properties with bacterial attachment," Journal of Membrane Science 157(1), 117-138. DOI: 10.1016/S0376-7388(98)00365-2

Leach, R. K., Bourell, D., Carmignato, S., Donmez, A., Senin, N., and Dewulf, W. (2019). "Geometrical metrology for metal additive manufacturing," CIRP Annals 68(2), 677-700. DOI: 10.1016/j.cirp.2019.05.004

Li, J., Idriss, A. I. I., Guo, Y., Wang, Y., Zhang, Z., Zhang, H., and Elfaki, E. A. (2020a). "Selective laser sintering and post-processing of sisal fiber/poly-(ether sulfone) composite powder," BioResources 15(1), 1338-1353. DOI:

10.15376/biores.15.1.1338-1353

Tiwari, S. K., Pande, S., Bobade, S. M., and Kumar, S. (2019). “Assessment of mechanical properties and flammability of magnesium oxide/PA12 composite material for SLS process," Rapid Prototyping Journal 25(1), 176-186. DOI: 10.1108/RPJ-07-2017-0145

Wohlers, T. (2005). "Rapid prototyping, tooling \& manufacturing state of the industry," in: Wohlers Report 2005, Wohlers Associates, Fort Collins, CO, USA.

Yu, Y., Guo, Y., Jiang, T., Jiang, K., Li, J., and Guo, S. (2017). "Laser sintering and postprocessing of a walnut shell/Co-PES composite," RSC Advances 7(37), 23176-23181. DOI: 10.1039/C7RA00775B

Yu, Y., Guo, Y., Jiang, T., Li, J., Jiang, K., and Zhang, H. (2018). "Study on process and parameter optimization of selective laser sintering of walnut shell composite powder," BioResources 13(2), 3017-3029. DOI: 10.15376/biores.13.2.3017-3029

Yuan, S., Bai, J., Chua, C. K., Wei, J., and Zhou, K. (2016). "Material evaluation and process optimization of CNT-coated polymer powders for selective laser sintering," Polymers 8(10), 370-387. DOI: 10.3390/polym8100370

Zeng, W., Guo, Y., Jiang, K., Yu, Z., and Liu, Y. (2012). "Preparation and selective laser sintering of rice husk-plastic composite powder and post processing," Digest Journal of Nanomaterials and Biostructures 7(3), 1063-1070.

Zeng, W., Guo, Y., Jiang, K., Yu, Z., Liu, Y., Shen, Y., Deng, J., and Wang, P. (2013). "Laser intensity effect on mechanical properties of wood-plastic composite parts fabricated by selective laser sintering," Journal of Thermoplastic Composite Materials 26(1), 125-136. DOI: 10.1177/0892705712461520 
Zhao, D., Guo, Y., Jiang, K., and Zhang, H. 2017. "Preparation and selective laser sintering of bamboo flour/copolyester composite and post-processing," Journal of Thermoplastic Composite Materials 30(8), 1045-1055. DOI:

$10.1177 / 0892705715616854$

Article submitted: January 13, 2020; Peer review completed: April 3, 2020; Revised version received: May 23, 2020; Accepted: May 25, 2020; Published: June 3, 2020. DOI: $10.15376 /$ biores. 15.3.5710-5724 